\title{
ヨー状態におけるフィールド風車回転翼面上の圧力分布*
}

\author{
前田太佳夫*1, 川渕 秀 之*2

\section{Pressure Distribution on Rotating Blade of Field Horizontal Axis Wind Turbine in Yawed Condition}

\author{
Takao MAEDA*3 and Hideyuki KAWABUCHI \\ ${ }^{* 3}$ Department of Mechanical Engineering, Mie University, \\ 1515 Kamihama-cho, Tsu-shi, Mie, 514-8507 Japan
}

\begin{abstract}
This paper shows the pressure distribution at $50 \%$ radial section on a rotor blade of $10 \mathrm{~m}^{-}$ diameter wind turbine in yawed operation. The pressure sensors were mounted on the blabe, and the local inflow angle and local dynamic pressure were measured with the use of five hole Pitot tubes at 1 chord length upwind of the blade leading edge. With the use of measured pressure distribution on the blade, the blade performances were calculated on the basis of the blade coordinate. As results of the measurements, the normal force coefficient in yawed condition decreases compared to those for non-yawed condition. Even if local angle of attack and the relative inflow velocity are the same condition, pressure distribution shows differences due to local slip angle. The tuffs flow ${ }^{-}$visualization on the rotating blade was carried out by setting the video camera on the rotating system. By the observation of tuffs behavior, the reduction of normal force coefficient is mainly caused by the separation.
\end{abstract}

Key Words : Fluid Mechinery, Wind Mill, Blade, Pressure Distribution, Stall, Unsteady Flow, Yaw Effects

\section{1. 緒言}

風力発電はエネルギー密度が小さいために効率よく 風からエネルギーを取り出すためには, 風車翼の性能 向上が必要不可欠である. 一般に, 数值計算等の二次 元解析によって翼形が設計され, 風洞実験により検証 される。これら開発された翼形を風車翼に使用する場 合には, 翼形特性に半径流や遠心力の効果を仮定して, 半径方向に複数の翼形を配置することにより風車翼は 設計される.しかし実機風車においては翼に流入する 流れは非定常であり,また, 回転翼周りの流れは遠心 力の効果に加えて三次元流れとなり非常に複雑であ る.そのため, 風車性能を予測するために必要とされ る翼に作用する非定常流体力を把握することが重要と なるが, 回転翼断面の空力特性をもとに詳細に示した 報告はわずかであり ${ }^{(1) ~(3)}$, 幅広い測定デー夕の提供が 求められている.

本研究では風車性能に大きく影響を及ぼす翼性能に 着目し, 翼車直径 $10 \mathrm{~m}$ のフィールド水平軸風車実機

* 原稿受付 2004 年 4 月 26 日.

*1 正員, 三重大学工学部 (514-8507 津市上浜町 1515).

*2 正員, 三重大学大学院工学研究科.

E-mail : maeda@mach.mie-u.ac.jp
翼面上の圧力測定を行い, フィールド実験で得られた 結果から, 風車翼に働く流体力の諸特性を明らかにし, 今後の翼開発と風車性能の向上に役立てることを目的 としている。これまで著者らは，二次元流れに近いと 考えられる $70 \% R$ 位置における流体力について明ら かにしてきた ${ }^{(4)}$. 本報では, 風向変化に対する風車翼 性能について明らかにするため, 三次元流れ成分が大 きいと思われる翼中間部 $(50 \% R$ 断面)の翼面上の圧 力測定を行い, ヨー角の違いによる翼性能の変化を明 らかにした。 また, 回転系にビデオカメラを搭載し, ヨー状態における翼面上のタフトの挙動を観察し, 可 視化に基づいて翼性能を考察した。

\section{2. おもな記 号}

$c$ : 翼弦長 $\mathrm{m}$

$C_{m}: 0.25 x / c$ の位置におけるモーメント係数 [式(4)]

$C_{n}$ : 翼厚方向力係数 $[$ 式 $(2)]$

$C_{p}$ : 圧力係数 [式 (1)]

$C_{t}:$ 翼弦方向力係数 $[$ 式 $(3)]$

$p:$ 遠心力を補正した翼面上圧力 $\mathrm{Pa}$

$p_{d}$ : 流入する流れの翼前緣から $1 c$ 上流での動圧 $\mathrm{Pa}$ 
$R:$ 翼車半径 $(=5 \mathrm{~m})$

$r$ : 翼半径位置 $\mathrm{m}$

$R e:$ 局所レイノルズ数 $=W c / \nu$

$U:$ 主流風速 $\mathrm{m} / \mathrm{s}$

$W:$ 翼前縁から $1 c$ 上流での流入速度 $\mathrm{m} / \mathrm{s}$

$x:$ 翼前縁から翼弦に沿った距離 $\mathrm{m}$

$y:$ 翼弦線に垂直方向への距離 $\mathrm{m}$

$\alpha:$ 翼前縁から $1 c$ 上流での局所迎え角。

$\beta:$ 翼前縁から $1 c$ 上流での局所滑り角

$\gamma:$ 翼端で $0^{\circ}$ としたねじり角。

$\theta:$ ピッチ角。

$\sigma:$ 風車 1 回転間の測定量の標準偏差

$\nu:$ 動粘性係数 $\mathrm{m}^{2} / \mathrm{s}$

$\Phi$ : 風車回転面に対する流入風の水平面内角度 ( $\exists$ 一角)

$\Psi:$ 測定翼が真上のときを $0^{\circ}$ とするアジマス 角。

添 字

$$
\begin{aligned}
C_{n} & : \text { 翼厚方向力係数 } \\
i & : i \text { 番めの圧力測定孔 } \\
\text { inst } & : \text { 瞬時値 } \\
W & : \text { 流入速度 } \\
\alpha & : \text { 局所迎え角 } \\
\beta & : \text { 局所滑り角 }
\end{aligned}
$$

\section{3. 実験装置および方法}

$3 \cdot 1$ 供試風車図 1 に供試フィールド風車の概 要を示す。供試フィールド風車は定格出力 $8 \mathrm{~kW}$, 翼 車直径 $10.0 \mathrm{~m}$, ハブ高さ $13.3 \mathrm{~m}$, 可変ピッチ機構を もつ 3 枚翼アップウィンド形水平軸風車である. 回転 方向は上流から風車回転面を見たときに, 反時計回り であり，ナセルの方向を風向に対して調整できる、測 定量および方法に関する詳細は前報である文献 (4)を
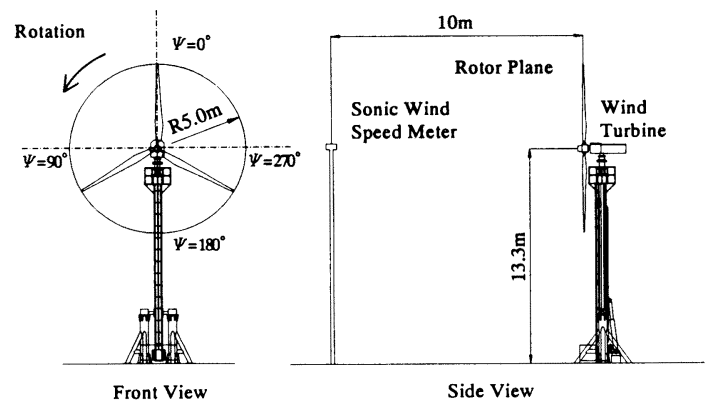

Fig. 1 Location of test wind turbine and wind speed meter
参照されたい.ここで, 圧力分布測定時のピッチ角制 御は, 供試風車の定格回転数が $80 \mathrm{rpm}$ であるので, この值を超えるとピッチ角を一定量だけ大きくし回転 数を下げ, また, 反対に, 回転数が下がりすぎるとピ ッチ角を一定量だけ小さくし回転数を上げるというよ うに, ピッチ角を連続的には変化させず, 定格回転数 が一定状態である程度続くよう手動で段階的に制御 し, 風車が定格回転数で運転しているときのみデー夕 を取得した。また，供試風車が設置されている実験場 の年間平均風向はほほ北西方向であるため, 風車から 北西方向へ $10.0 \mathrm{~m}$ の位置のハブ高さと同じ高さには, 主流風速を測定するための三次元超音波流速計を設け てある，なお，実験は風向が北西方向のときにのみ実 施した。

$3 \cdot 2$ 供試翼 供試翼は翼端半径 $5.0 \mathrm{~m}, \mathrm{FRP}$ 製 テーパねじり翼で, 翼形は翼根元部に DU 91-W 2250 翼形, 翼中間部分から翼端部にかけて DU 93-W-

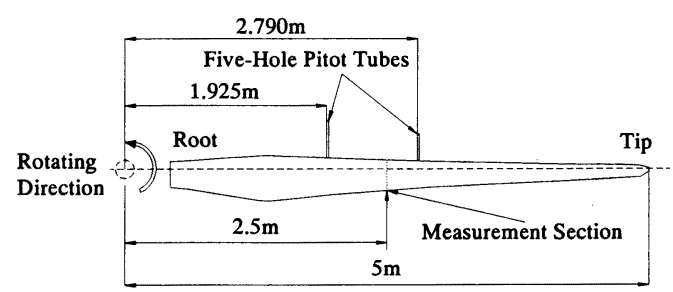

Fig. 2 Test blade

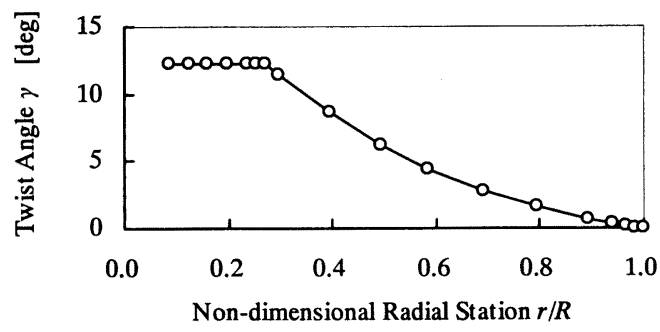

(a) Twist angle distribution

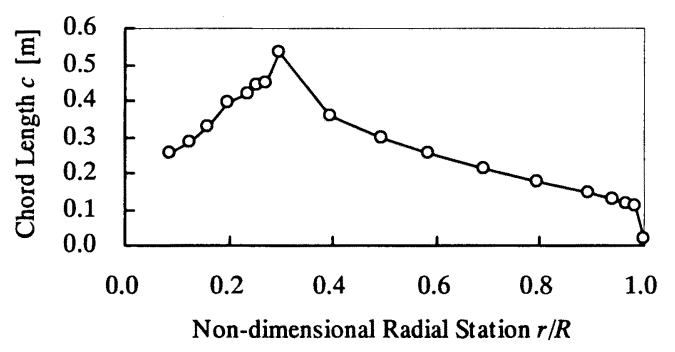

(b) Chord length distribution

Fig. 3 Distribution of twist angle and chord length of test blade 


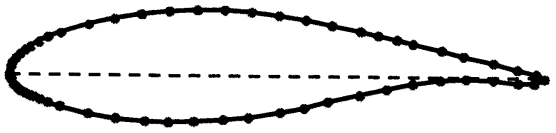

Fig. 4 Position of pressure taps on measurement section

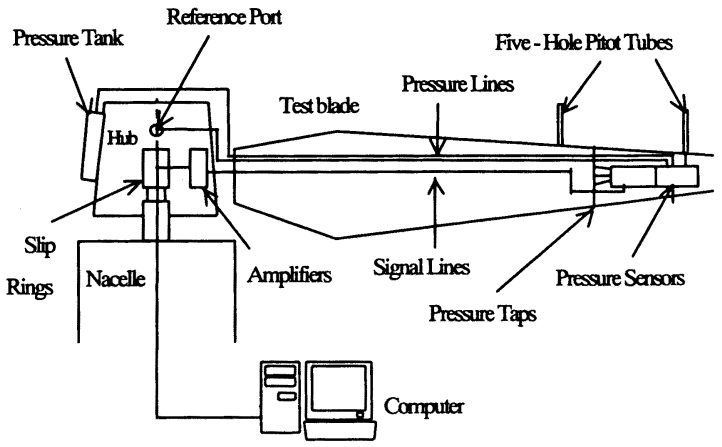

Fig. 5 Measurement system

210 翼形，および NACA 63-618 翼形を用い，その他 の翼断面は補間によって寸法を定めてある．本研究て は，翼回転中心から $2.5 \mathrm{~m}$ の断面の $50 \% R$ 位置にお いて圧力測定を行った。 また, 圧力測定断面に流入す る流れの動圧および流入角を測定するため, 図 2 に示 すように圧力測定断面を挟んだ 2 箇所の翼前縁から 1 $c$ 上流に五孔ピトー管を取付けてある. 図 3 には供試 翼のねじり角分布および翼弦長分布を示す，翼端から 翼根元までのねじり角は $12^{\circ}$ である。

図 4 は $50 \% R$ 位置における圧力測定孔の配置を示 す. 圧力測定部には, 直径 $0.4 \mathrm{~mm}$ の圧力測定孔が断 面に 60 個設けてあり, 圧力こう配の大きな翼前縁部 に集中して多くの測定孔を設けてある.

$3 \cdot 3$ 測定系 図 5 に圧力測定系を示す. 圧力測 定には半導体式圧力センサを使用し，翼面上の圧力測 定孔で検知された圧力は，圧力センサでアナログ電圧 信号に変換され, 信号増幅器で増幅された後, スリッ プリングを介して静止系に送られ，A-D ボードから コンピュータに取り込まれサンプリングされる。サン プリング周波数は $90 \mathrm{~Hz}$ であり，これは回転数が 80 $\mathrm{rpm}$ のとき, 回転位置角 (以後, アジマス角と記述す

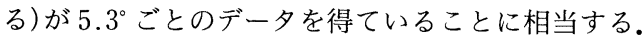
アジマス角は，エンコーダによって測定され，測定翼 がいちばん上にきた状態を $0^{\circ} と し($ 図 1 ), 反時計回り に測定される.

本研究では, 主流風速の非定常性および誘導速度に よる翼幅方向への流入速度分布の不均一性等による影 響を考慮して，翼前縁から $1 \mathrm{c}$ 上流にて測定断面をは

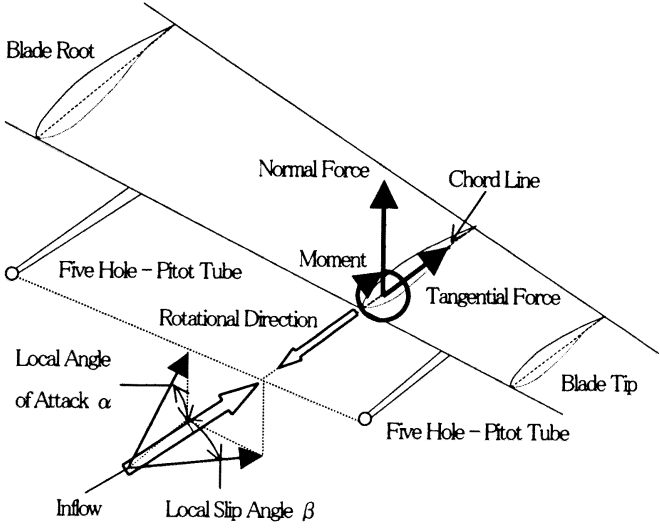

Fig. 6 Definition of Normal force, tangential force, moment, local angle of attack and local slip angle

さむ 2 本の五孔ピト一管で測定した流入角および動圧 を，それぞれ測定断面位置の值に線形補間し，局所迎 え角, 局所滑り角，および流入風の動圧と定義した。

翼面上圧力值は, 流入速度, 迎え角, 翼表面形状に よって変化するため, 無次元量として圧力係数により データを整理した．本研究では，翼断面上の第 $i$ 番め の圧力測定孔から得られた圧力 $p_{i}$ を流入風の動圧 $p_{d}$ で無次元化し次の式から圧力係数 $C_{p_{i}}$ を求めた。

$$
C_{p_{i}}=p_{i} / p_{d}
$$

ここで, 圧力 $p_{i}$ は回転による遠心力の影響を補正し てある.また一般的に，翼に発生する力は，十分上流 の一様流に対して垂直な力を揚力, 平行な力を抗力と 定義する。しかしながら, 風車回転翼に対しては十分 上流の一様流を定義できないため, 風車翼の性能を評 価する方法として, 図 6 に示すように翼そのものを基 準として, 翼弦に垂直な力と翼弦に平行な力とに分解 して翼の性能を評価する, 本報では, この翼弦に垂直 な力を翼厚方向力, 翼弦に平行な力を翼弦方向力と記 述する.これらの力を翼前縁から $1 c$ 上流で測定した 動圧で無次元化した量を翼厚方向力係数 $C_{n}$, 翼弦方 向力係数 $C_{t}$, および $x / c=0.25$ を中としたモーメ ント係数 $C_{m}$ とし，次式のように定義する.

$$
\begin{aligned}
& C_{n}=\sum_{i=1}^{n} \frac{p_{i}}{p_{d}} \frac{\Delta x_{i}}{c}=\frac{1}{c} \sum_{i=1}^{n} C_{p_{i}} \Delta x_{i} \\
& C_{t}=\sum_{i=1}^{n} \frac{p_{i}}{p_{d}} \frac{\Delta y_{i}}{c}=\frac{1}{c} \sum_{i=1}^{n} C_{p_{i}} \Delta y_{i} \\
& C_{m}=\frac{1}{c^{2}} \sum_{i=1}^{n}\left(C_{p_{i}} l_{t i} \Delta x_{i}+C_{p_{i}} l_{n i} \Delta y_{i}\right)
\end{aligned}
$$

ここで, $\Delta x_{i}$ は $i$ 番めの測定孔位置における翼弦方向 に沿った微小長さ, $\Delta y_{i}$ は $i$ 番めの測定孔位置におけ る翼弦線に垂直な方向への微小長さ, $l_{n i}$ は翼厚方向 
のモーメントアームの長さ, $l_{t i}$ 翼弦方向のモーメント アームの長さである． $C_{n}$ は翼正圧面から負圧面への 方向を正とし， $C_{t}$ は翼前縁から後縁への方向を正， $C_{m}$ は $x / c=0.25$ を中心に時計回りを正とした。また， 翼前方での半径方向流れとして局所滑り角 $\beta$ を定義 し，ピト一管を基準として流入風が半径外向きのとき に正とする。

本報では，図 7 に示すように主流風速に対する風車 ナセルの角度をヨー角 $\Phi$ と定義し， $\Phi$ は $-45^{\circ}$ から $+45^{\circ}$ まで $15^{\circ}$ 間隔で変化させて実験を行った，風車 回転面に対する流入風向については，風車は風向制御 を行うことができるが,つねに変動している風向を完 全に追尾することはできないので, 風向が風車に対し て $\pm 7.5^{\circ}$ の変動範囲内での測定データをヨー角 $\Phi$ と 定めた．例えば，ヨー角 $\Phi=30^{\circ}$ のデータとは, $22.5^{\circ}$ $<\Phi \leqq 37.5^{\circ}$ のヨー角範囲内のデータを示す.ここで, ヨー角は超音波流速計から得た風向の瞬時值とナセル に取付けられたロータリエンコーダの出力の瞬時值か ら決定しており，この場合には超音波流速計から風車

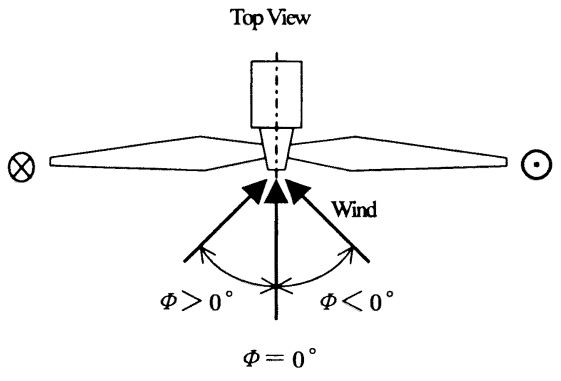

Fig. 7 Definition of yaw angle $\Phi$
回転面までの距離 $10 \mathrm{~m}$ が問題となる.この点は五孔 ピトー管から得た動圧から導出した流入速度と，超音 波流速計で得た速度を測定断面における速度成分に変 換して導出した流入速度を，アジマス角 $\Psi=90,270^{\circ}$ で比較した結果, 誤差の瞬時值が約 $5 \%$ 以下であり $\mathrm{BIN}$ 平均後の誤差の值は約 4\%であったことから, $\mathrm{BIN}$ 平均により影響を軽減可能であることを確認し ている。

また, $50 \% R$ 断面において表面タフト法による可 視化実験も行った. タフトの間隔は, 翼弦方向には翼 弦長の約 $20 \%$ 間隔をとり, 半径方向には斜流による夕 フト同士の影響を考慮し $100 \mathrm{~mm}$ 間隔で張り付けた. また圧力測定も同時に行うために測定断面への影響を 考慮し, 測定断面より翼根元側 $100 \mathrm{~mm}$ から翼端側 $100 \mathrm{~mm}$ までの範囲にはタフトを張り付けないように した.タフトは毛系(直径 $2.5 \mathrm{~mm}$ )を使用し, 長さは 流れに対しての応答性および視認性を考慮し, タフト 取付断面の翼弦長の約 $15 \%$ とした。撮影には, CCD ワイヤレスカラーカメラを用い, 翼のフランジにカメ ラ台を取付けその上に固定した. 撮影された画像デー 夕は，ボス上に取付けた付属アンテナから地上の受信 アンテナへ転送し, 信号ケーブルを通り, パーソナル コンピュータに取り込まれる。サンプリング周波数 は, $30 \mathrm{~Hz}$ でアジマス角 $16^{\circ}$ ごとのデータに相当する.

\section{4. 実験結果と考察}

$4 \cdot 1$ ヨー角の違いによる局所迎え角に対する測定 值の変化 本報で示すフィールド実験データは, サ ンプリング周波数が $90 \mathrm{~Hz}$, 総測定時間は約 $5146 \mathrm{~s}$ である。このときの実験条件は表 1 に示すとおり，デ

Table 1 Experimental condition (Inside of parentheses are BIN averaged value for every rotor rotation)

\begin{tabular}{|c|c|c|c|}
\hline & \multicolumn{3}{|c|}{ Yaw Angle $\Phi[\mathrm{deg}]$} \\
\cline { 2 - 4 } & -45 & 0 & 45 \\
\hline Wind Speed $U[\mathrm{~m} / \mathrm{s}]$ & $0.2 \sim 11.4$ & $0.1 \sim 12.1$ & $0.1 \sim 13.4$ \\
& $(5.4 \sim 6.1)$ & $(5.1 \sim 5.4)$ & $(5.3 \sim 5.5)$ \\
\hline Inflow Velocity $W$ at $1 c$ & $11.8 \sim 34.1$ & $13.2 \sim 31.8$ & $5.6 \sim 38.1$ \\
Upwind of Blade Leading & $(17.9 \sim 25.9)$ & $(22.9 \sim 23.4)$ & $(13.4 \sim 25.6)$ \\
Edge [m/s] & $2.4 \times 10^{5} \sim 7.1 \times 10^{5}$ & $2.7 \times 10^{5} \sim 6.6 \times 10^{5}$ & $1.2 \times 10^{5} \sim 7.9 \times 10^{5}$ \\
& $\left(3.9 \times 10^{5} \sim 5.7 \times 10^{5}\right)$ & $\left(5.0 \times 10^{5} \sim 5.1 \times 10^{5}\right)$ & $\left(4.0 \times 10^{5} \sim 5.6 \times 10^{5}\right)$ \\
\hline Reynolds Number $R e$ & $2.6 \sim 7.4$ & $2.6 \sim 7.4$ & $2.6 \sim 7.4$ \\
& $(4.9 \sim 5.1)$ & $(5.1 \sim 5.3)$ & $(4.6 \sim 4.7)$ \\
\hline Pitch Angle $\theta$ [deg] & $1.8 \sim 84.9$ & $1.8 \sim 263.1$ & $1.3 \sim 140.8$ \\
$(3.9 \sim 5.0)$ & $(4.6 \sim 4.9)$ & $(4.4 \sim 4.6)$ \\
\hline Section Speed Ratio $\omega / U$ & 865 & 2069 & 2885 \\
\hline Rotation Number & & & \\
\hline
\end{tabular}




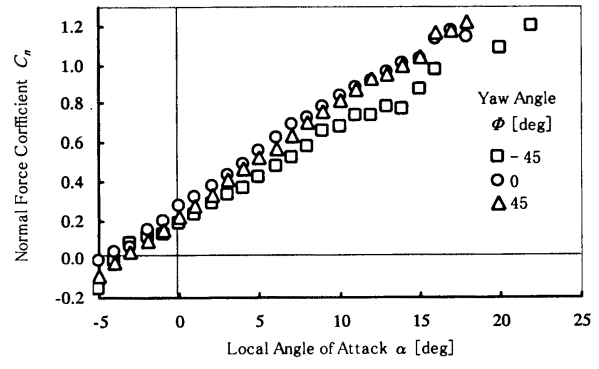

(a) Normal force coefficient $C_{n}$ against local angle of attack $\alpha$

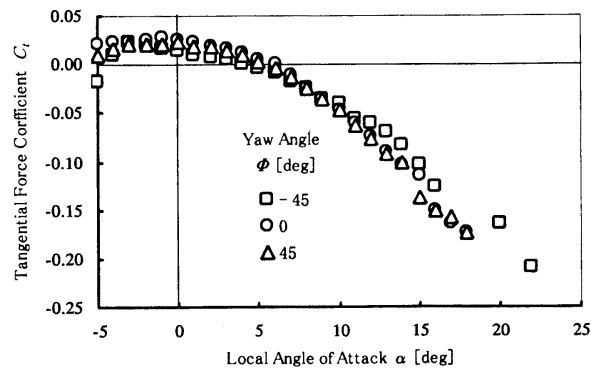

(b) Tangential force coefficient $C_{t}$ against local angle of attack $\alpha$

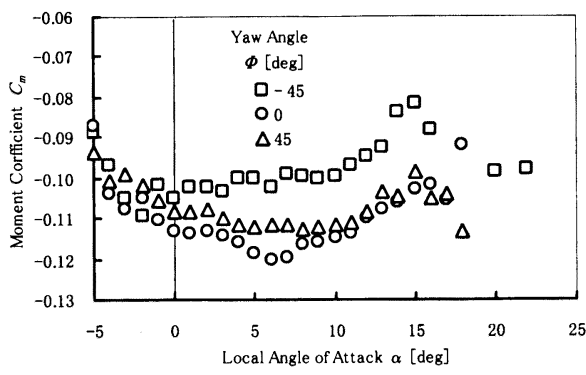

(c) Moment coefficient $C_{m}$ against local angle of attack $\alpha$

Fig. 8 Section characteristics in several yawed conditions

ータごとに流入風の状態およびロータ回転数が異な る.そこでまず，風車 1 回転ごとに平均值および標準 偏差を求め, そのあと局所迎え角 $\alpha$ を $1^{\circ} こ ゙ と に \mathrm{BIN}$

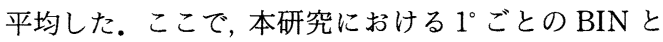
は, $\left(\alpha-0.5^{\circ}\right)$ 以上, $\left(\alpha+0.5^{\circ}\right)$ 未満の $\alpha$ が $1^{\circ}$ の幅の範 囲に含まれるデータの平均值のことである.

図 8 は, $50 \% R$ 断面における翼性能をヨー角が $\Phi$

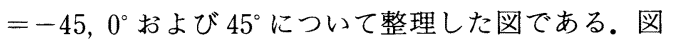
8(a) は, 局所迎え角 $\alpha$ に対する翼厚方向力係数 $C_{n}$ の図である.ヨー角が $\Phi=0^{\circ}$ の場合と比較して, ヨー 角が $\Phi=45^{\circ}$ では局所迎え角全域にわたり $C_{n}$ が若干

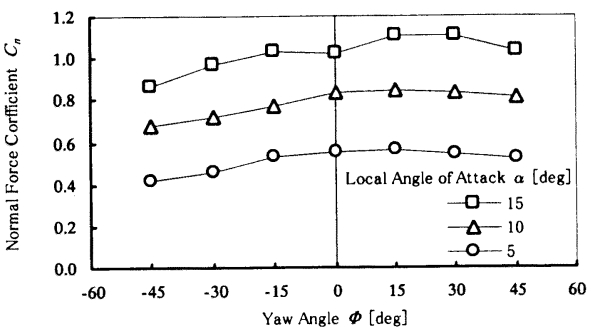

Fig. 9 Normal force coefficient $C_{n}$ against yaw angle $\Phi$

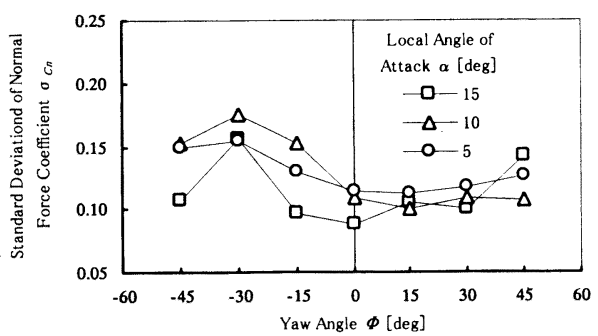

(a) Normal force coefficient $C_{n}$

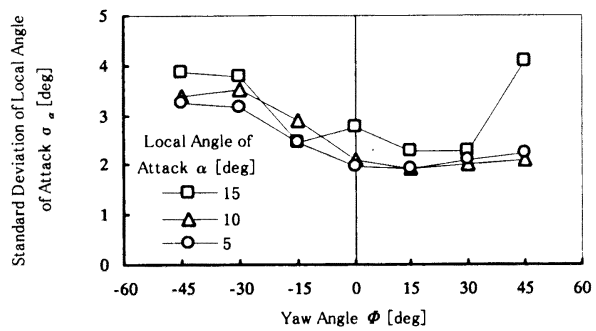

(b) Local angle of attack $\alpha$

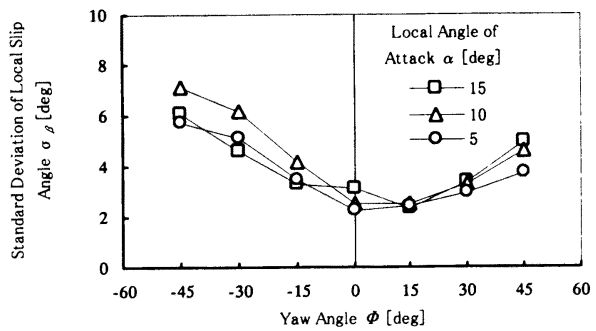

(c) Local slip angle $\beta$

Fig. 10 Standard deviation against yaw angle $\Phi$

小さくなる傾向が見られる.ヨー角が $\Phi=-45^{\circ}$ でも 同じく $\Phi=0^{\circ}$ の場合と比較して, 局所迎え角全域にわ たり $C_{n}$ が小さくなるが, その減少量は大きい. 図 8(b) は, 局所迎え角 $\alpha$ に対する翼弦方向力係数 $C_{t}$ の図である. ヨー角が $\Phi=-45,0^{\circ}$ およ゙ $45^{\circ}$ を比較 しても $C_{t}$ に明確な傾向の違いは見られない。図 $8(\mathrm{c})$ は, 局所迎え角 $\alpha$ に対するモーメント係数 $C_{m}$ の図である.ヨー角が $\Phi=0^{\circ}$ の場合と比較して, ヨー 
角が $\Phi=45^{\circ}$ では局所迎え角 $-5^{\circ} \leqq \alpha \leqq 10^{\circ}$ の範囲で $C_{m}$ が若干大きくなる傾向が見られる. $コ$ ー角が $\Phi=$ $-45^{\circ}$ でも同じく $\Phi=0^{\circ}$ の場合と比較して, 局所迎え 角全域にわたり $C_{m}$ が大きくなる. 図 $8(\mathrm{a}) \sim(\mathrm{c})$ か らヨー角による違いは, $C_{n}$ および $C_{m}$ の值に現れ, 特 に, ヨ一角 $\Phi=-45^{\circ}$ では翼性能の変化が大きいこと がわかる。

図 9 は, ヨ一角 $\Phi$ に対する翼厚方向力係数 $C_{n}$ を局 所迎え角 $\alpha$ ごとに整理したものである. $=0^{\circ}$ を基準としてヨー角の值が小さくなるにしたが い, $C_{n}$ の值は小さくなる傾向が見られる. 一方, ヨ 一角 $\Phi$ が大きくなるときにも， $C_{n}$ が小さくなる傾向 が見られるが, その減少量はヨー角 $\Phi$ が負の場合と 比較して小さい.このことから, ヨ一角 $\Phi$ の值が正 と負の場合では $C_{n}$ の值の変化が非対称となることが わかる.これは, 垂直・水平方向速度こう配(以後, ウ インドシアと記述する)をもつ主流風の方向に対する 風車翼の移動方向が，ヨー角 $\Phi$ およびアジマス角 $\Psi$ により大きく変化するためと考えられる.

図 10 は, 風車 1 回転間の翼特性の標準偏差を局所 迎え角 $\alpha$ ごとに BIN 平均したものである. 図 $10(\mathrm{a})$ は, ヨー角 $\Phi$ に対する翼厚方向力係数 $C_{n}$ の標準偏差 $\sigma_{C n}$ の図である. $ヨ$ 角が $\Phi=0^{\circ}$ を基準としてヨー角 の値が小さくなるにしたがい, $\sigma_{C n}$ が大きくなる傾向 が見られる.一方，ヨー角の值が大きくなるときも， $\sigma_{C n}$ が大きくなる傾向が見られるが, ヨー角の值が負 のときと比較して増加量は小さい.図 10(b)は, ヨ一 角 $\Phi$ に対する局所迎え角 $\alpha$ の標準偏差 $\sigma_{\alpha}$ の図であ る.こちらも，ヨー角 $\Phi$ が小さくなるにしたがい， $\sigma_{\alpha}$ が大きくなり図 $10(\mathrm{a})$ と同じ傾向を示す. 図 $10(\mathrm{c})$ は, ヨー角 $\Phi$ に対する局所滑り角 $\beta$ の標準偏差 $\sigma_{\beta}$ の 図である.こちらも，ヨ一角 $\Phi$ が小さくなるにした がい， $\sigma_{\beta}$ が大きくなり図 $10(\mathrm{a})$ および図 $10(\mathrm{~b})$ と同 じ傾向を示す。これらのことから，ヨー角の值が負の ときには風車 1 回転間に翼に作用する流体力の変動が 大きくなることがわかる.

\section{$4 \cdot 2 \quad \exists$ 角の違いによるアジマス角に対する測定}

値の変化 $4 \cdot 1$ 節においてヨー角の正負による翼性 能の変化を示したが, この変化の空間依存性を調べる ため, アジマス角ごとに諸量の変化を考察する，実験 条件は $4 \cdot 1$ 節と同じく表 1 に示すとおりである。この

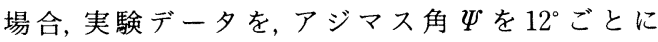

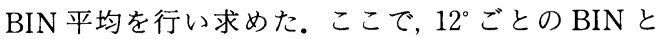
は $\left(\Psi-6^{\circ}\right)$ 以上, $\left(\Psi+6^{\circ}\right)$ 末満の, $\Psi$ が $12^{\circ}$ の幅の範 囲に含まれるデータの平均值のことである.

図 11 は, 翼の諸性能をヨー角が $\Phi=-45,0^{\circ} お よ$

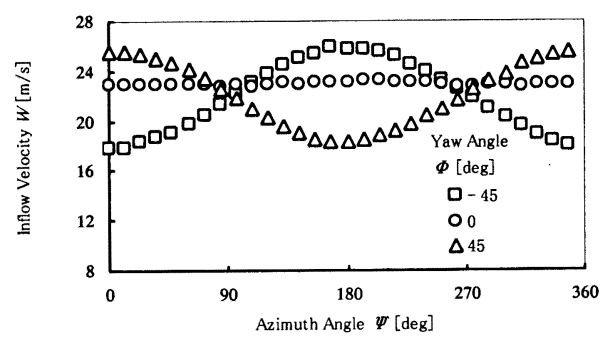

(a) Inflow velocity $W$

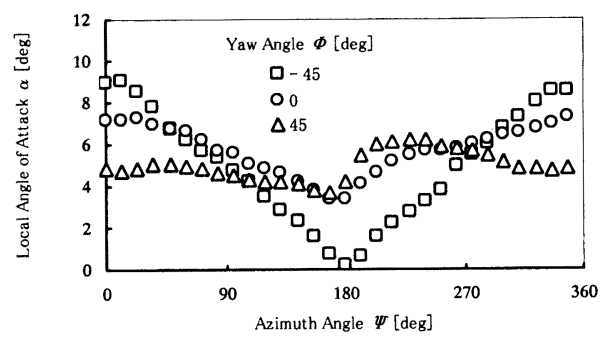

(b) Local angle of attack $\alpha$

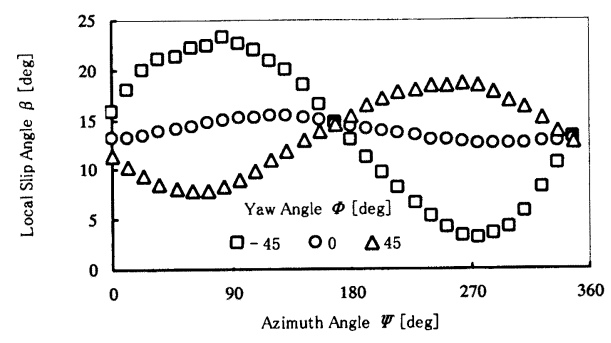

(c) Local slip angle $\beta$

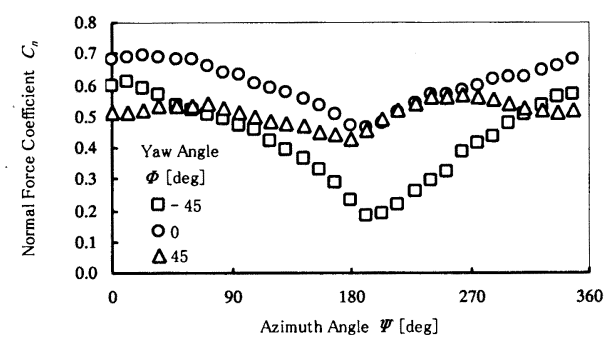

(d) Normal force coefficient $C_{n}$

Fig. 11 Change of section characteristics due to azimuth angle $\Psi$ in several yawed conditions

び $45^{\circ}$ について整理したものを示す. 図 11 ( a ) は, ア ジマス角 $\Psi$ に対する流入速度 $W$ の変化を示す。ま ず，ヨ一角が $\Phi=0^{\circ}$ ではアジマス角 $\Psi$ が変化しても 流入速度 $W$ は一定である. しかし, 大気境界層の影 響を考慮した場合, 流入風速 $W$ に変動が現れるはず だが現れていない.これには, 水平方向のウィンドシ アが影響していると考えられる，この点については後 
日報告する. ヨー角が $\Phi=45^{\circ}$ ではアジマス角 $\Psi=0^{\circ}$ のとき, 主流風速は速く翼に対して向かい風として作 用するため流入速度 $W$ が大きくなり, 一方, アジマ ス角 $\Psi=180^{\circ}$ では主流風速は遅く追い風として作用 するため流入速度 $W$ は小さくなる. 反対にヨー角 $\Phi$ $=-45^{\circ}$ ではアジマス角 $\Psi=0^{\circ}$ のとき, 主流風速は速 く追い風として作用するため流入速度 $W$ が小さくな り,アジマス角 $\Psi=180^{\circ}$ では主流風速は遅く向かい 風として作用するため流入速度 $W$ が大きくなる.こ のように, ウィンドシアをもつ主流風の中では, ヨー 角 $\Phi$ とアジマス角 $\Psi$ により大きく流入速度 $W$ が変 化することがわかる。

図 11(b)は，アジマス角 $\Psi$ に対する局所迎え角 $\alpha$ の変化を示す．ヨー角が $\Phi=0^{\circ}$ ではアジマス角が $\Psi$ $=0^{\circ}$ で $\alpha$ 值が大きく, $\Psi=180^{\circ}$ では小さい.これは, 大気境界層の影響により翼が上方にあるアジマス角が $\Psi=0^{\circ}$ で主流風速 $U$ が大きく, 翼が下方にある $\Psi=$ $180^{\circ}$ では $U$ が小さくなるためである. ヨー角が $\Phi=$ $45^{\circ}$ ではアジマス角が $\Psi=180^{\circ}$ で $\alpha$ が小さく, $\Psi=$ $200^{\circ}$ では大きい.これはタワーが障害となり近傍の 流れが押しのけられた結果, 主流風速の減少をまねく ためと考えられる.ヨー角が $\Phi=-45^{\circ}$ ではアジマス 角が $\Psi=0^{\circ}$ で $\alpha$ は大きく, 流入速度 $W$ は最小值に近 い. $\Psi=180^{\circ}$ では $\alpha$ は小さく, 流入速度 $W$ は最大值 に近い.ここで, ヨー角 $\Phi=-45,45^{\circ}$ を比較すると 図 11 ( a )の流入速度 $W$ の変動量は同じ程度であるに もかかわらず, $\alpha$ の変動量はヨー角 $\Phi=-45^{\circ}$ のほう が大きい.このことからも，ウィンドシアの影響が見 てとれる。

図 11(c)は, アジマス角 $\Psi$ に対する局所滑り角 $\beta$ の変化を示す. $ヨ$ 角が $\Phi=0^{\circ}$ のとき, アジマス角 $\Psi$ と局所滑り角 $\beta$ 関係はほぼ一定である. ヨー角が $\Phi=45^{\circ}$ のとき, アジマス角が $\Psi=90^{\circ}$ で $\beta$ 值は最小 值に近く, $\Psi=270^{\circ}$ で $\beta$ は最大值に近い.そこでは 流入速度 $W$ は同じであるが，翼端がハブ高さと同じ 高さにあるアジマス角 $\left(\Psi=90^{\circ}\right)$ では翼はナセルより も風上側にある. 一方, $\Psi=270^{\circ}$ では翼はナセルより も風下側にある. $コ 一$ 角が $\Phi=-45^{\circ}$ のときは, $\Phi=$ $45^{\circ}$ の場合と反対の傾向となるが, $\beta$ 值の変動量はよ り大きくなる、ヨ一角を有する場合にウィンドシアを もつ主流速が，回転するボス部分および直方体形状の ナセル周りを通過するとき, 発生する渦構造は複雑に なると考えられ, その影響が $\beta$ 值の変動量の大きさと なって現れていると考えられる. Grant らはこの可能 性を示唆する可視化結果を報告している(5). また，こ こでもやはりヨー角 $\Phi=-45,45^{\circ}$ を比較すると $\beta$ の

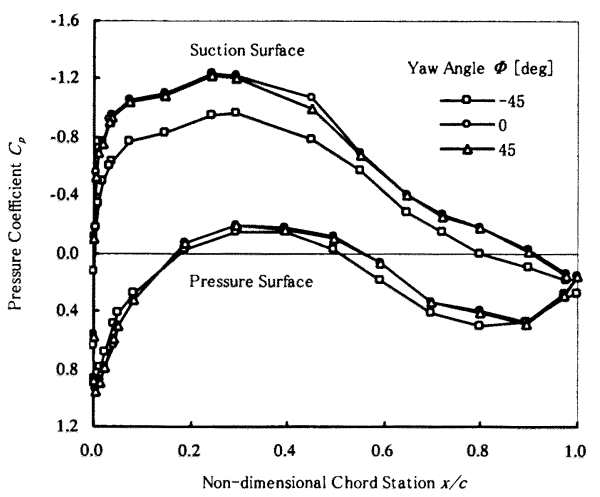

Fig. 12 Pressure distribution at $\alpha=10$ degrees in several yawed conditions

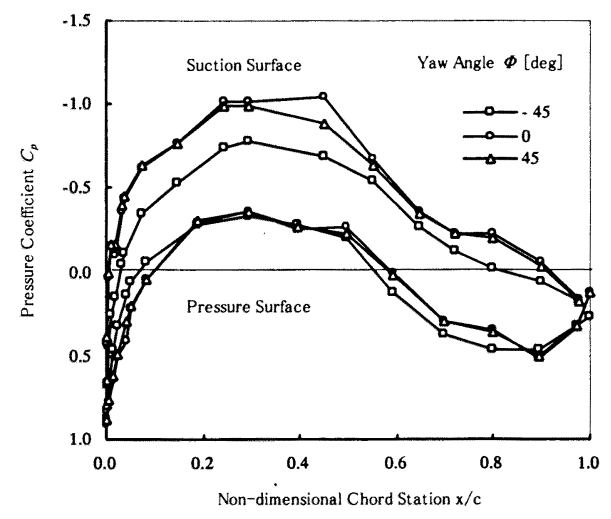

Fig. 13 Pressure distribution at $\alpha=5.5$ degrees at $\Psi=$ 270 degrees in several yawed conditions

変動量はヨー角 $\Phi=-45^{\circ}$ のほうが大きいことがわか る.

図 11(d)は,アジマス角 $\Psi$ に対する翼厚方向力係 数 $C_{n}$ の変化を示す. 図 $11(\mathrm{a}) \sim(\mathrm{c})$ の結果から, ア ジマス角が $\Psi=90^{\circ}$ および $270^{\circ}$ のとき $\alpha$ および $W$ の値がヨー角によらずほぼ一致しており，このときの $\beta$ および $C_{n}$ の值を比較するとアジマス角が $\Psi=270^{\circ}$ でヨー角の違いによる大きな違いが見られる。さら に, 図 11(b) および図 $11(\mathrm{~d})$ においてアジマス角が $\Psi \leqq 90^{\circ}$ おび $\Psi \geqq 270^{\circ}$ の範囲に注目して $\alpha$ と $C_{n}$ の 値を比較すると， $\alpha$ の值が最も大きくなるヨー角は $\Phi$ $=-45^{\circ}$ であるのに対し， $C_{n}$ の值が最も大きくなるヨ 一角は $\Phi=0^{\circ}$ である. 二次元流れにおいては， $C_{n}$ の 値が $\alpha$ のに依存すると考えられるが，風車回転翼に

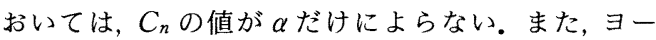
角 $\Phi=-45,45^{\circ}$ を比較して流入速度 $W$ の変動量が 同じ程度であっても $\alpha$ および $\beta$ 值の変動量はヨー角 


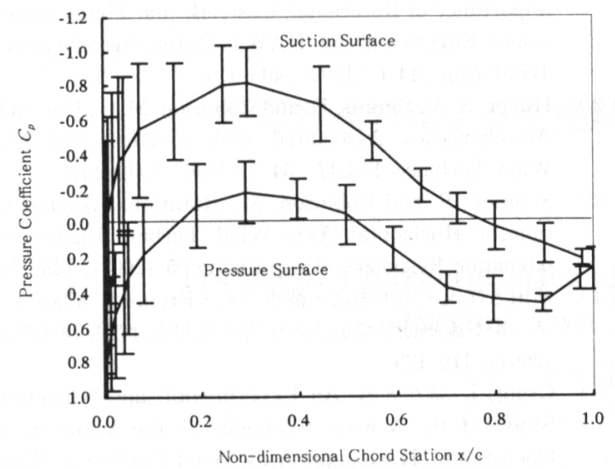

Fig. 14 Pressure distribution with standard deviation at $\alpha=6.7$ degrees at $\Psi=48$ degrees in $\Phi=-45$ degrees

の符号によって非対称になる。これらウィンドシアが もたらす変動が, 図 9 において変動量の非対称および ヨー角 $\Phi=-45^{\circ}$ において $C_{n}$ の值が大幅に減少する 原因であると考えられる。

$4 \cdot 3$ ヨー角の違いによる圧力分布の比較 図 12 は, 図 9 において局所迎え角 $\alpha=10^{\circ}$ のときの圧力分 布をヨー角 $\Phi$ ごとに整理したものを示す. ヨー角 $\Phi$ $=0^{\circ}$ の場合と比較して, ヨー角 $\Phi=45^{\circ}$ では $0.3<x / c$ $<0.6$ の範囲で負圧面側の負圧が減少している. 正圧 面側はヨー角の値による違いは見られない.ヨー角 $\Phi=-45^{\circ}$ では負圧面側の負圧が全体的に減少してい る. 一方, $0.4 \leqq x / c \leqq 0.9$ の範囲では圧力が上昇して いる. ヨー角 $\Phi=-45^{\circ}$ では圧力分布に明確な違いが 現れることがわかる.

図 13 は, 図 11 において $W$ および $\alpha$ の值は一致し ているが $C_{n}$ および $\beta$ の值が異なっていた, アジマス 角 $\Psi=270^{\circ}$ のとき圧力分布をヨー角 $\Phi$ ごとに整理 したものを示す. ヨー角 $\Phi=0^{\circ}$ の場合と比較して, ヨ 一角 $\Phi=45^{\circ}$ では負圧面側 $0.3 \leqq x / c \leqq 0.5$ の範囲で負 圧が減少している以外に, 違いは見られない.ヨー角 $\Phi=-45^{\circ}$ では全体的に負圧面側の負圧が減少してい る. 一方, 正圧面側は $0.5 \leqq x / c \leqq 0.9$ の範囲で圧力の 上昇が見られる。 $\alpha$ おび $W$ の值がほぼ一致してい る場合でも， $\beta$ の值が異なると圧力分布に明確な違い が現れることがわかる。

図 14 は, ヨー角 $\Phi=-45^{\circ}$ に打けるアジマス角 $\Psi$ $=48^{\circ}$ のときの圧力分布および標準偏差を示す．後述 $4 \bullet 4$ 節, 図 15 の可視化結果に関連して, 負圧面の圧力 分布に注目する.このとき, 局所迎え角の標準偏差 $\sigma_{\alpha}=4.7^{\circ}$, 局所滑り角の標準偏差 $\sigma_{\beta}=4.6^{\circ}$, 流入速度 の標準偏差 $\sigma_{W}=2.1 \mathrm{~m} / \mathrm{s}$ である. $\alpha, \beta$ および $W$ の 変動に伴い, 圧力係数 $C_{p}$ の標準偏差が大きくなって

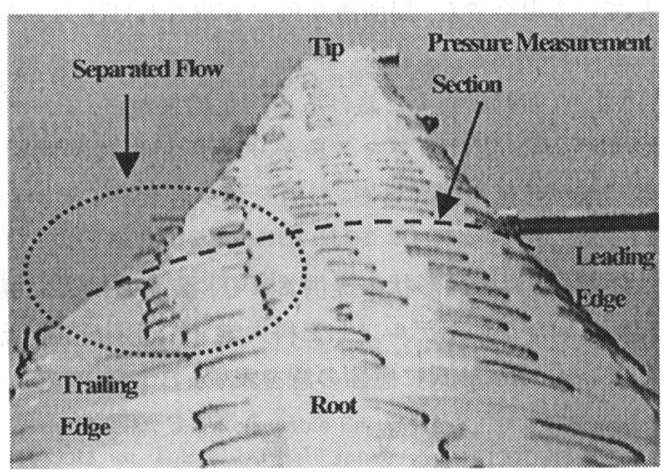

Fig. 15 Flow Visualization on Suction Surface at $\Psi=0$ degree $\left(\alpha_{\text {inst }}=10.6\right.$ degrees, $\beta_{\text {inst }}=9.5$ degrees, $\Phi_{\text {inst }}=-49.1$ degrees and $\operatorname{Re}_{\text {inst }}=3.5 \times 10^{5}$ )

いる. しかし, $x / c=0.45,0.8$ では圧力係数 $C_{p}$ の標 準偏差が大きいにもかかわらず，その中間領域の 0.45 $<x / c<0.8$ では小さくなっている. $4 \cdot 4$ 節では, この $\alpha, \beta$ および $W$ の変動による影響が小さい領域にお ける翼面上の可視化図を示す。

$4 \cdot 4$ 回転翼面上における流れの可視化 図 15 は, ヨー角 $\Phi=-45^{\circ}$ (瞬時ヨー角 $\Phi_{\text {inst }}=-49.1^{\circ}$ ) にお ける回転翼面上の流れをタフト法により可視化した写 真を示す。このとき翼端は頂点 $\Psi=0^{\circ}$ にあり, 局所 迎え角が $\alpha_{i n s t}=10.6^{\circ}$ と小さいにもかかわらず，最大 キャンバ位置から後縁にかけて, はく離が発生してい

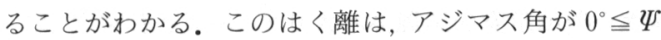
$\leqq 90^{\circ}$ の範囲で確認されている。一方，アジマス角が $90^{\circ}<\Psi<360^{\circ}$ の範囲では, はく離が観測されなかっ た.ただし，アジマス角が $300^{\circ} \leqq \Psi<360^{\circ}$ の範囲て は, 後縁付近においてタフトが振動せずに翼表面から 浮上していることが観測されている.これらのことか ら, 図 9 および図 $11(\mathrm{~d})$ で見られたヨー角が $\Phi=$ $-45^{\circ}$ のとき $C_{n}$ 值が大幅に減少する傾向は, はく離 の発生が抢もな原因であるといえる。

\section{5. 結言}

フィールド風車回転翼面上の $50 \% R$ 断面における 圧力分布を測定し，ヨー角の違いに着目して考察した 結果，以下のことが明らかとなった。

（1）風車がヨー状態の場合には, 翼厚方向力係数 $C_{n}$ は, ヨー状態でない場合よりも低下する。

（2）本研究においては, ヨ一角の值が正の場合と 負の場合で局所迎え角 $\alpha$ ごとに整理した $C_{n}$ の值は非 対称となり, 特に, ヨー角の值が負のときにはヨー角 の翼性能へ及ぼす影響が大きい。 
（3）局所迎え角 $\alpha$ および流入速度 $W$ がほぼ一致 している場合でも, 局所滑り角 $\beta$ が異なれば圧力分布 に違いが現れる。

（4）回転翼面上における可視化結果から，ヨー角 が $\Phi=-45^{\circ}$ ではアジマス角が $0^{\circ} \leqq \Psi \leqq 90^{\circ}$ の範囲で, はく離が発生し著しく $C_{n}$ の值を減少させることがわ かった。

最後に, 翼断面形状の提供および, 装置の構築に協 力していただいたデルフト工科大学 A. Bruining氏 と R. van Rooji 氏に感謝の意を表す.

\section{文献}

(1) Madsen, H. A. and Christensen, H., On the Relative importance of Rotational, Unsteady and Three-Dimensional Effects on the HAWT Rotor Aerodynamics, Wind Eng., 14-6 (1990), 405-415.

(2) Huyer, S. A., Simms, D. and Robinson, M. C., Unsteady Aerodynamics Associated with a Horizontal-Axis Wind Turbine, AIAAJ ., 34-7 (1996), 1410-1419.

(3) Schreck, S. and Robinson, M., Rotational Augmentation of Horizontal Axis Wind Turbine Blade Aerodynamic Response, Wind Energy, 5 (2002), 133-150.

（4）前田太佳夫・川渕秀之・清水幸丸・Bruining, Albert., ᄀ イールド風車回転翼面上の圧力分布測定, 機論, 70-693, B (2004), 119-125.

(5) Grant, I., ほか8 名, An Experimental and Numerical Study of the Vortex Filaments in the Wake in an Operational, Horizontal-Axis, Wind Turbine, J. Wind. Eng. Ind. Aerodyn, 85 (2000), 177-189. 